\title{
Front Matter: Volume 10171
}

, "Front Matter: Volume 10171," Proc. SPIE 10171, Smart Materials and Nondestructive Evaluation for Energy Systems 2017, 1017101 (12 June 2017); doi: 10.1117/12.2279928

Event: SPIE Smart Structures and Materials + Nondestructive Evaluation and Health Monitoring, 2017, Portland, Oregon, United States 


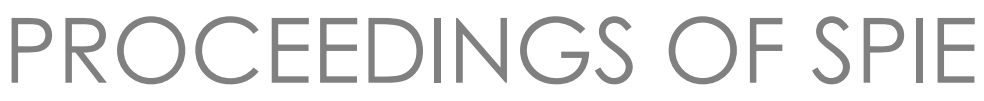

\title{
Smart Materials and Nondestructive Evaluation for Energy Systems 2017
}

\author{
Norbert G. Meyendorf \\ Editor
}

\section{7-28 March 2017 \\ Portland, Oregon, United States}

Sponsored by

SPIE

Co-sponsored by

OZ Optics, Ltd. (United States)

Polytec, Inc. (United States)

Fiberguide Industries (United States)

Frontiers Media (Switzerland)

\section{Cooperating Organization}

Jet Propulsion Laboratory (United States)

Published by

SPIE 
The papers in this volume were part of the technical conference cited on the cover and title page. Papers were selected and subject to review by the editors and conference program committee. Some conference presentations may not be available for publication. Additional papers and presentation recordings may be available online in the SPIE Digital Library at SPIEDigitallibrary.org.

The papers reflect the work and thoughts of the authors and are published herein as submitted. The publisher is not responsible for the validity of the information or for any outcomes resulting from reliance thereon.

Please use the following format to cite material from these proceedings:

Author(s), "Title of Paper," in Smart Materials and Nondestructive Evaluation for Energy Systems 2017, edited by Norbert G. Meyendorf, Proceedings of SPIE Vol. 10171 (SPIE, Bellingham, WA, 2017) Seven-digit Article CID Number.

ISSN: 0277-786X

ISSN: 1996-756X (electronic)

ISBN: 9781510608276

ISBN: 9781510608283 (electronic)

Published by

SPIE

P.O. Box 10, Bellingham, Washington 98227-0010 USA

Telephone +1 3606763290 (Pacific Time) · Fax +1 3606471445

SPIE.org

Copyright (c) 2017, Society of Photo-Optical Instrumentation Engineers.

Copying of material in this book for internal or personal use, or for the internal or personal use of specific clients, beyond the fair use provisions granted by the U.S. Copyright Law is authorized by SPIE subject to payment of copying fees. The Transactional Reporting Service base fee for this volume is $\$ 18.00$ per article (or portion thereof), which should be paid directly to the Copyright Clearance Center (CCC), 222 Rosewood Drive, Danvers, MA 01923. Payment may also be made electronically through CCC Online at copyright.com. Other copying for republication, resale, advertising or promotion, or any form of systematic or multiple reproduction of any material in this book is prohibited except with permission in writing from the publisher. The CCC fee code is 0277-786X/17/\$18.00.

Printed in the United States of America.

Publication of record for individual papers is online in the SPIE Digital Library.

\section{SPIE. DIGITAL \\ SPIEDigitalLibrary.org}

Paper Numbering: Proceedings of SPIE follow an e-First publication model. A unique citation identifier (CID) number is assigned to each article at the time of publication. Utilization of CIDs allows articles to be fully citable as soon as they are published online, and connects the same identifier to all online and print versions of the publication. SPIE uses a seven-digit CID article numbering system structured as follows:

- The first five digits correspond to the SPIE volume number.

- The last two digits indicate publication order within the volume using a Base 36 numbering system employing both numerals and letters. These two-number sets start with 00, 01, 02, 03, 04, 05, 06, 07, 08, 09, OA, OB ... 0Z, followed by 10-1Z, 20-2Z, etc. The CID Number appears on each page of the manuscript. 


\title{
Contents
}

\author{
$\checkmark$ Authors \\ vii Conference Committee
}

\section{SESSION 1 ENERGY STORAGE AND HARVESTING I}

1017102 Air curtain development: an energy harvesting solution for hinged doors [10171-1]

1017103 Experimental verification and optimization of a linear electromagnetic energy harvesting device [10171-2]

1017104 A study of water electrolysis using ionic polymer-metal composite for solar energy storage [10171-3]

1017105 Optimized MPPT-based converter for TEG energy harvester to power wireless sensor and monitoring system in nuclear power plant [10171-4]

\section{SESSION 2 ENERGY STORAGE AND HARVESTING II}

$10171072 \mathrm{D}$ numerical analysis of energy harvesting in oscillating heat pipe using piezoelectric transducers [10171-6]

1017108 Battery charge and health state monitoring via ultrasonic guided-wave-based methods using built-in piezoelectric transducers [10171-7]

1017109 Electrochemical behaviors of a wearable woven textile Li-ion battery consisting of a core and wound electrode fibers coated with active materials [10171-8]

10171 OA An energy harvesting solution based on the post-buckling response of non-prismatic slender beams [10171-30]

\section{SESSION $3 \quad$ WIND ENERGY}

10171 OC Development of an embedded thin-film strain-gauge-based SHM network into 3D-woven composite structure for wind turbine blades [10171-11]

10171 OD Optimal statistical damage detection and classification in an experimental wind turbine blade using minimum instrumentation [10171-12]

$10171 \mathrm{OE}$ Mode extraction on wind turbine blades via phase-based video motion estimation [10171-13]

10171 OF Scheduling structural health monitoring activities for optimizing life-cycle costs and reliability of wind turbines [10171-14] 
10171 OG Application of model predictive control for optimal operation of wind turbines [10171-15]

SESSION 4 NDE OF ENERGY COMPONENTS AND SYSTEMS

$101710 \mathrm{~J}$ Time-frequency analysis of guided ultrasonic waves used for assessing integrity of rock bolts [10171-17]

SESSION $5 \quad$ NDE AND MONITORING OF ENERGY COMPONENTS AND SYSTEMS

$10171 \mathrm{OL}$ Data collection and analysis software development for rotor dynamics testing in spin laboratory [10171-19]

1017100 Experimental investigation of wave dispersion in hardened concrete and reference liquid media [10171-22]

10171 OP Novel dynamic thermal characterization of multifunctional concretes with microencapsulated phase change materials [10171-23]

10171 OR Detection and characterization of exercise induced muscle damage (EIMD) via thermography and image processing [10171-25]

10171 OS Briquetting and carbonization of biomass products for the sustainable productions of activated carbons [10171-31]

POSTER SESSION

10171 OT Nanocomposite functional paint sensor for infrared detecting and energy harvesting [10171-9]

10171 OU Building environment assessment and energy consumption estimation using smart phones [10171-26]

$10171 \mathrm{OV}$ Local elasticity mapping of aluminum matrix composites using scanning acoustic microscopy [10171-27]

10171 oW Cement-based materials with graphene nanophase [10171-28] 


\title{
Authors
}

Numbers in the index correspond to the last two digits of the seven-digit citation identifier (CID) article numbering system used in Proceedings of SPIE. The first five digits reflect the volume number. Base 36 numbering is employed for the last two digits and indicates the order of articles within the volume. Numbers start with 00, 01, 02, 03, 04, 05, 06, 07, 08, 09, OA, OB...0Z, followed by 10-12, 20-2Z, etc.

\author{
Abdul-Aziz, Ali, OL \\ Aggelis, Dimitrios G., 00 \\ Alamir, Mohammed, OS \\ Alavi, Amir H., OA \\ Alomari, Almuatasim, OT \\ Alzahrani, Naif, OS \\ Anakok, Isil, 05 \\ Arble, Daniel, OL \\ Archer, Edward, OC \\ Asmatulu, Ramazan, OS \\ Avdelidis, N. P., OR \\ Bang, S., 09 \\ Batra, Ashok K., OT \\ Bohara, Bir B., OT \\ Borchani, Wassim, OA \\ Cabeza, Luisa F., OP \\ Cao, Pei, OG \\ Chang, Fu-Kuo, 08 \\ Chen, Zheng, 04 \\ Cotana, Franco, OP \\ Currie, James R., OT \\ D'Alessandro, Antonella, OP \\ Dalla, P. T., OW \\ Dassios, K., OW \\ Dayal, Vineed, 02 \\ Deli, C. K., OR \\ Exarchos, D. A., OW \\ Fabiani, Claudia, OP \\ Forde, Micheal, OC \\ Georgoulas, G., OR \\ Giakas, G., OR \\ Glenn, Chance M., OT \\ Grosse, Christian U., 00 \\ Hanish Nithin, Anu, OF \\ Hasni, Hassene, OA \\ Hoell, Simon, OD \\ lliopoulos, Sokratis N., 00 \\ Jamurtas, A. Z., OR \\ Jia, Yingqi, OU \\ Jiao, Pengcheng, OA \\ Jin, Xin, OU \\ Kappatos, V., OR \\ Karimibavani, Bahareh, OS \\ Karvelis, P., OR \\ Keow, Alicia, 04 \\ Khorasgani, Nasrin B., OS \\ Kim, C., 09 \\ Kopsaftopoulos, Fotis, 08 \\ Kordatou, T. Z., OV
}

Kovi, M., OR

Ladpli, Purim, 08

Lajnef, Nizar, OA

Lee, Soobum, 02, 03

$\mathrm{Li}$, Xiangli, OU

Malm, Fabian, 00

Mao, Zhu, OE

Matikas, T. E., OV, OW

McClain, Amy P., OS

Mcllhagger, Alistair, OC

McLaughlin, James, OC

Monroe, John G., 07

Mullen, Christopher, 03

Myers, Oliver, 07

Nardari, Raphael, 08

Niezrecki, Christopher, OE

Omenzetter, Piotr, OD, OF

Pisello, Anna Laura, OP

Poozesh, Peyman, OE

Rasool, Shafqat, OC

Sarrafi, Aral, OE

Shamsaei, Nima, 07

Stepinski, Tadeusz, 0J

Tang, J., OG

Theodorakeas, P., OR

Thompson, Scott, 07

Tragazikis, I. K., OV, OW

Tsiokanos, A., OR

Ubertini, Filippo, OP

Vaidya, Sajiree, 07

Wang, Zihan, OU

Weafer, Bryan, OC

Woike, Mark, OL

Xing, Shaoxu, 05

Yuan, Yuan, OG

Yun, S., 09

Zhang, Li, OU

Zhao, Dongning, OC

Zhao, Xuefeng, OU

Zhou, D., 09

Zuo, Lei, 05 
Proc. of SPIE Vol. 10171 1017101-6

Downloaded From: https://www.spiedigitallibrary.org/conference-proceedings-of-spie on 25 Apr 2023 Terms of Use: https://www.spiedigitallibrary.org/terms-of-use 


\title{
Conference Committee
}

\author{
Symposium Chairs
}

Jayanth N. Kudva, NextGen Aeronautics, Inc. (United States)

Theodoros E. Matikas, University of loannina (Greece)

Symposium Co-chairs

Tribikram Kundu, The University of Arizona (United States)

Gregory W. Reich, Air Force Research Laboratory (United States)

Conference Chair

Norbert G. Meyendorf, lowa State University (United States)

Conference Co-chairs

Theodoros E. Matikas, University of loannina (Greece)

Kara J. Peters, North Carolina State University (United States)

Conference Program Committee

Ali Abdul-Aziz, NASA Glenn Research Center (United States)

Nicolas P. Avdelidis, Université Laval (Canada)

George Y. Baaklini, NASA Glenn Research Center (United States)

Leonard Bond, lowa State University (United States)

Michael Dalichow, Quality Network Inc. (United States)

Peter Heilmann, arxes-tolina GmbH (Germany)

Manfred Johannes, South African Institute for Non-Destructive Testing (South Africa)

Vassilios Kappatos, University of Southern Denmark (Denmark)

Michael Kroening, Pontifícia Universidade Católica do Rio de Janeiro (Brazil)

Michele Meo, University of Bath (United Kingdom)

Alexander Michaelis, Fraunhofer IKTS (Germany)

Bernd Michel, Fraunhofer-Institut für Elektronische Nanosysteme (Germany)

Piotr Omenzetter, University of Aberdeen (United Kingdom)

Tadeusz Stepinski, AGH University of Science and Technology (Poland)

Mark R. Woike, NASA Glenn Research Center (United States)

H. Felix Wu, U.S. Department of Energy (United States)

Dong-Jin Yoon, Korea Research Institute of Standards and Science (Korea, Republic of)

Lingyu Yu, University of South Carolina (United States) 
Session Chairs

1 Energy Storage and Harvesting I

Mark R. Woike, NASA Glenn Research Center (United States)

2 Energy Storage and Harvesting II

Mark R. Woike, NASA Glenn Research Center (United States)

3 Wind Energy

Norbert G. Meyendorf, lowa State University (United States)

$4 \quad$ NDE of Energy Components and Systems

Norbert G. Meyendorf, lowa State University (United States)

5 NDE and Monitoring of Energy Components and Systems

Ali Abdul-Aziz, Kent State University (United States) 